\title{
The role of sustainable construction in sustainable development
}

\author{
Agnieszka Czajkowska* \\ Department of Strength of Materials, Concrete and Bridges Structures, Kielce University of \\ Technology, Poland
}

\begin{abstract}
Humans and the actions they take to improve their quality of life lead to the disturbance of the processes occurring in the natural environment. These processes should not be stopped while the solution should be found to help humans coexist with nature. The ecological and social problems and the resulting threats have become an inspiration for the development of the concept of sustainable development. Sustainable development has led to the necessity to implement changes towards balancing all areas of human activity, including the construction sector. Factors affecting sustainable development are present in many phases of building creation and use. The most important of them have been characterized and discussed. The article describes the main requirements for sustainable development, contained in laws and regulations, at every stage of building construction. Furthermore, the study analysed the share of individual sectors of the economy in consumption of energy resources. The focus was on the consumption of raw materials in the sector of industry and construction and the sector of households. The analysis shows that the industry and construction sector has a large share in hard coal consumption, heat and electricity. The hard coal consumption is increasing in the sector of households.
\end{abstract}

\section{The idea of sustainable development}

The first action plans to protect the Earth and its natural resources were discussed during the World Conference in Stockholm in 1972 ("Only one Earth") [1-4]. The ecological and social problems and the resulting threats have become an inspiration for the development of the concept of sustainable development. The term "sustainable development" was first used in the Brundtland Report (1987) developed by the UN World Commission on Environment and Development. [1, 3-6] The concept of sustainable development does imply limits - not absolute limits but limitations imposed by the present state of technology and social organization on environmental resources and by the ability of the biosphere to absorb the effects of human activities [1]. Sustainable development is a necessity. It applies to everyone, starting from large corporations, to small enterprises, to every single person who realizes this idea by waste sorting [4-7]. As far as the environment is concerned, the Earth is shrinking and if we do not start to look after it, then for the next generations there may

\footnotetext{
*Corresponding author: a_czajkowska@o2.pl
} 
not be enough resources. Sustainability includes more than environmental sustainability. Sustainable development includes political, social and cultural issues.

Critical objectives for environment and development policies that follow from the concept of sustainable development include [1]:

- reviving growth;

- changing the quality of growth;

- meeting essential needs for jobs, food, energy, water, and sanitation;

- ensuring a sustainable level of population;

- conserving and enhancing the resource base:

- reorienting technology and managing risk; and

- merging environment and economics in decision making.

Pursuit of sustainable development requires [1]:

- a political system that secures effective citizen participation in decision making.

- an economic system that is able to generate surpluses and technical knowledge on a

- self-reliant and sustained basis a social system that provides for solutions for the tensions arising from disharmonious development.

- a production system that respects the obligation to preserve the ecological base for

- development,

- a technological system that can search continuously for new solutions,

- an international system that fosters sustainable patterns of trade and finance, and

- an administrative system that is flexible and has the capacity for self-correction.

Facing the challenges of the sustainable development in the construction sector is especially important due to the fact that this industry processes huge amounts of mass and energy resources. In practice, sustainable development in the construction sector means the necessity of further economic development while limiting the consumption of matter (energy and mass) and construction of environmentally-friendly buildings. The role of sustainable construction in sustainable development is significant due to:

- the importance of construction in the development of society, economy, - the amount of resources consumed.

Sustainable development is considered in three aspects: environmental, social and economic. These aspects can be applied to sustainable construction (Fig.1).

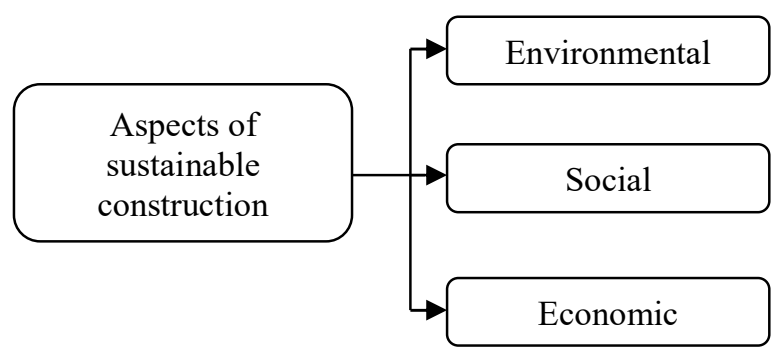

Fig. 1. Aspects of sustainable development in construction.

In construction, these aspects can be characterized as follows [3-6, 10-11]:

1) The economic aspect includes:

- reduction of the building's operating costs, after applying modern solutions both in the sphere of design, applied materials, exploitation,

- reduction of demolition costs,

2) The environmental aspect concerns the reduction of energy, water, raw materials, greenhouse gas emissions and waste production; 
3) Social aspect - raising life quality, interest in health, comfort and safety of users or residents, eg by guaranteeing adequate exchange and quality of indoor air.

The aim of the article is to show what is the impact of construction on the natural environment in comparison with other industries.

\section{Actions for sustainable construction}

Methods used to limit the negative impact on the natural environment in the construction sector include:

- eco-innovations in production of construction materials,

- promotion of construction of passive houses,

- the government subsidies for ecological investments,

- modernization of the heating systems using renewable energy sources, thermomodernization, modernization of heat and water systems, rationalization of water consumption, waste sorting and recycling,

- use of materials from recycling and renewable resources in the construction sector, new technologies of treatment and saving water.

Initiatives aimed at sustainable building should be implemented at each stage of the construction sector. The most effective are adequate legal regulations and the respective restrictions. [6-8] The first legal act in Poland which concerned sustainable development was the act of 7 July 1994 on land development. Sustainable development was also defined by the Art. 5 of the Constitution of the Republic of Poland, which says "The Republic of Poland shall safeguard the independence and integrity of its territory and ensure the freedoms and rights of persons and citizens, the security of the citizens, safeguard the national heritage and shall ensure the protection of the natural environment pursuant to the principles of sustainable development."

In the life cycle of a building, five areas can be distinguished:

- Project design

- Raw material extraction and production of construction materials

- Construction,

- Use,

- Demolition of a building object

Table 1 presents selected legal acts supporting actions for sustainable construction for each phase of the life cycle.

Table 1. Selected legal acts supporting activities for sustainable construction

\begin{tabular}{|l|l|}
\hline $\begin{array}{l}\text { Phases in the } \\
\text { building process } \\
\text { cycle }\end{array}$ & \multicolumn{1}{|c|}{ Type of legal act } \\
\hline Project design & $\begin{array}{l}\text { Amendment of the directive on ecological principles of product design - } \\
2009 / 125 / \text { EU - objective: implementation of the assessment of ecological } \\
\text { aspects to the design of products related to energy consumption (ErP), taking } \\
\text { into account all phases of its life cycle. }\end{array}$ \\
\hline $\begin{array}{l}\text { Raw material } \\
\text { extraction and } \\
\text { production of } \\
\text { construction } \\
\text { materials }\end{array}$ & $\begin{array}{l}\text { The Regulation (EU) No 305/2011 of the European Parliament and of the } \\
\text { Council of 9 March 2011 laying down harmonised conditions for the marketing } \\
\text { of construction products and repealing Council Directive 89/106/EEC. } \\
\text {-The Act of 8 September 2016. Construction Products (Journal of Laws } \\
\text { of 2016, item 1570) } \\
\text { - ENERGY LABEL Directive on energy labels for energy-related products } \\
2010 / 30 / \text { UE, }\end{array}$ \\
\hline
\end{tabular}




\begin{tabular}{|l|l|}
\hline & $\begin{array}{l}\text { - The CPR Regulation that lays down harmonised conditions for the marketing } \\
\text { of construction products (EU) 305/2011, } \\
\text { - EPBD „Recast” Directive on energy performance buildings 2010/31/UE } \\
- \text { The Act of 27 April 2001 - Environmental Protection Law ( Journal of Laws } \\
\text { of 2008 No. 25, item 150, as amended). }\end{array}$ \\
\hline Construction & $\begin{array}{l}\text { - The Building Law Act of 7 July 1994 (Journal of Laws 2017, Pos. 1332) with } \\
\text { further amendments }\end{array}$ \\
\hline Use & $\begin{array}{l}\text { - The Directive 2009/28/EC on the promotion of the use of energy from } \\
\text { renewable sources. (sets targets for all member states, such that Poland will } \\
\text { reach a 15\% share of energy from renewable sources by 2020) }\end{array}$ \\
$-\begin{array}{l}\text { The Act of 20 February 2015 on renewable sources of energy (Journal of } \\
\text { Laws of 2015, Pos. 478) will help reach a 15\% share of energy from } \\
\text { renewable sources in total energy consumption by 2020. } \\
- \text { EN ISO 50001:2011 Energy management systems - Requirements with } \\
\text { guidance for use }\end{array}$ \\
\hline Demolition & $\begin{array}{l}- \text { The Building Law Act of 7 July 1994 (Journal of Laws 2017, Pos. 1332) with } \\
\text { further amendments }\end{array}$ \\
\hline
\end{tabular}

Source : [13-17]

The EN ISO 50001:2011 standard stipulated concrete guidelines [PN-EN ISO 50001:2012]:

- identification of current and expected energy consumption,

- formulation and implementation of the energy policy,

- definition of the areas of substantial energy consumption and plants to reduce this consumption,

- implementation of the system of energy consumption measurement and monitoring using the Deming cycle.

\section{Analysis of the negative impact on the natural environment by sectors of the economy with particular focus on the construction industry}

The negative impact on the environment is associated mainly with the use of natural resources and the emission of harmful substances. In 2015, Poland emitted 10.2 tons of carbon dioxide per capita. The average for the European Union is 8.8 tons per capita. [18]

The construction sector is linked to many other sectors of the economy. It affects the natural environment in a direct and indirect way. Considering its negative impact on the natural environment, linkage with other sectors should be taken into account. Figure 2 presents selected industries related to the construction sector. On the basis of statistical data, the impact of individual sectors of the economy on the natural environment was presented. Particular attention was given to the construction industry. The article presents the percentage share of economic sectors in:

-consumption of hard coal,

- consumption of heat,

-consumption of electricity,

- greenhouse gas emissions,

- waste generation.

Figure 3 presents the emission of greenhouse gases in various sectors of the economy. From the analysis of the drawing, it can be read that the biggest share in the carbon dioxide emission has energy industries (53\%). 


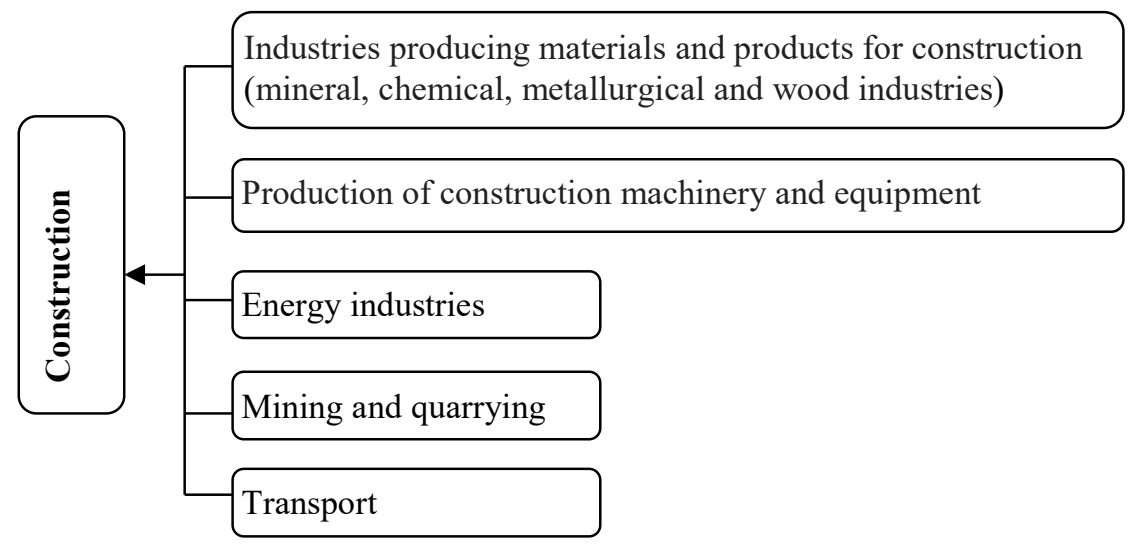

Fig. 2. Industries related to the construction sector.

The consumption of renewable energy sources is low. The most renewable energy sources in Poland are: geothermal energy, solar energy, biomass energy. Their consumption should be more popular. Waste generation by type of activity is presented in Figure 4.

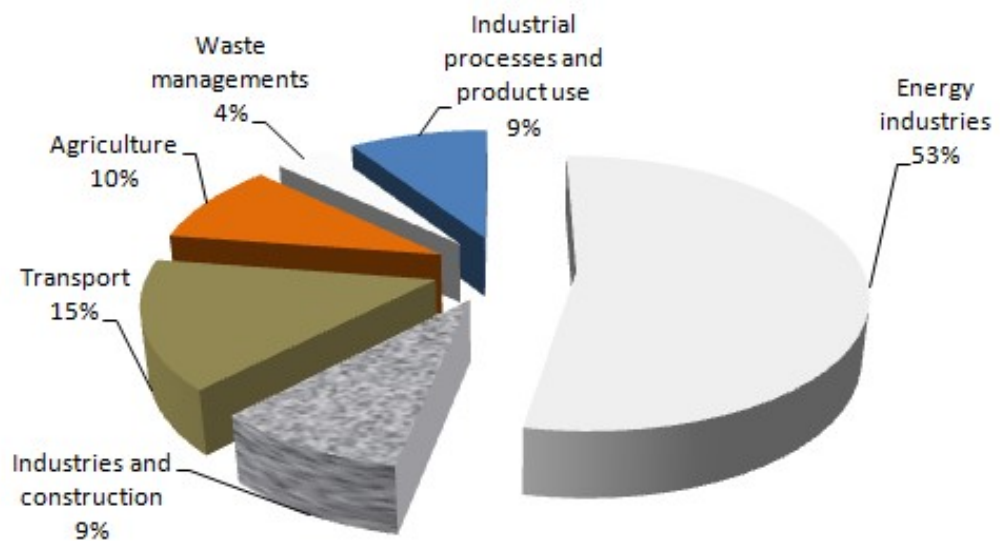

Fig. 3. Emission of greenhouse gases for individual sectors of the economy.

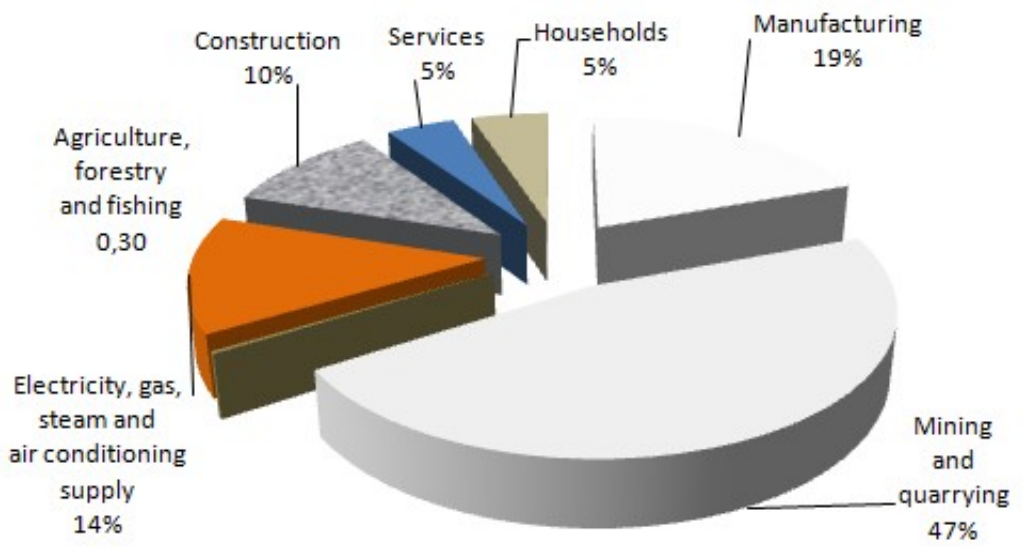

Fig. 4. Generation of waste for individual sectors of the economy. 
The analysis of the figure shows that mining and quarrying generates the most waste (47\%). The second place is occupied by manufacturing - 19\%. The structure of hard coal, heat and electricity consumption in 2016 for individual sectors of the economy is presented in Fig. $5 \div 7$.

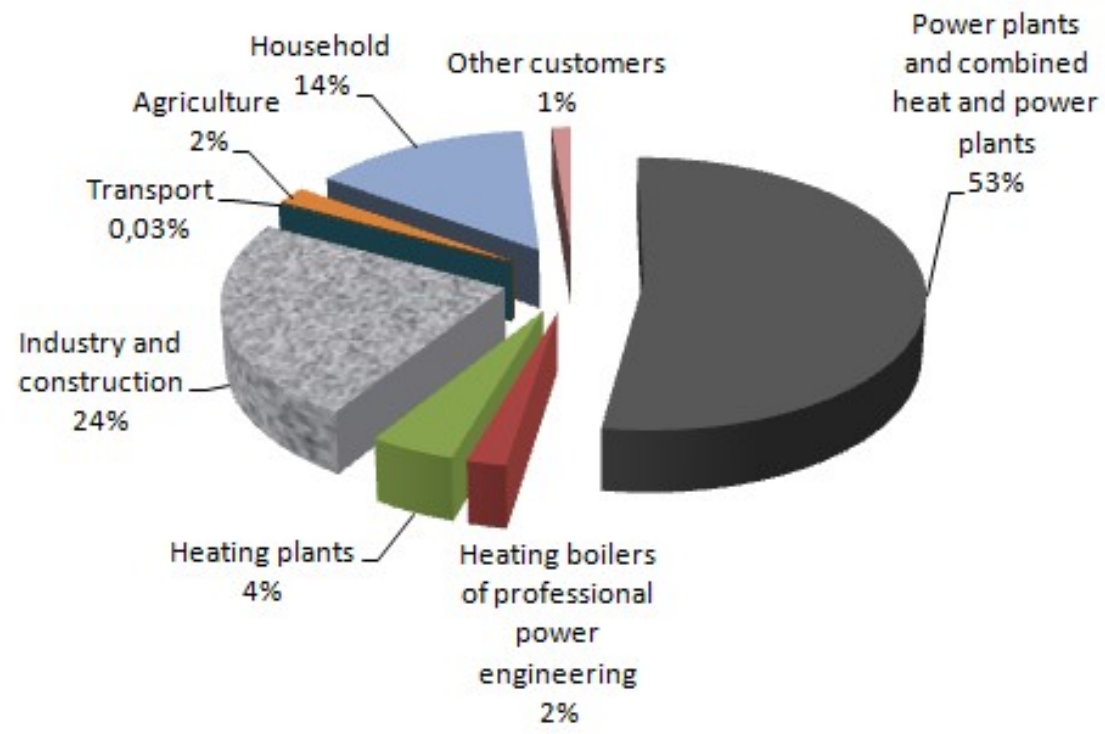

Fig. 5. The structure of hard coal consumption [19-21].

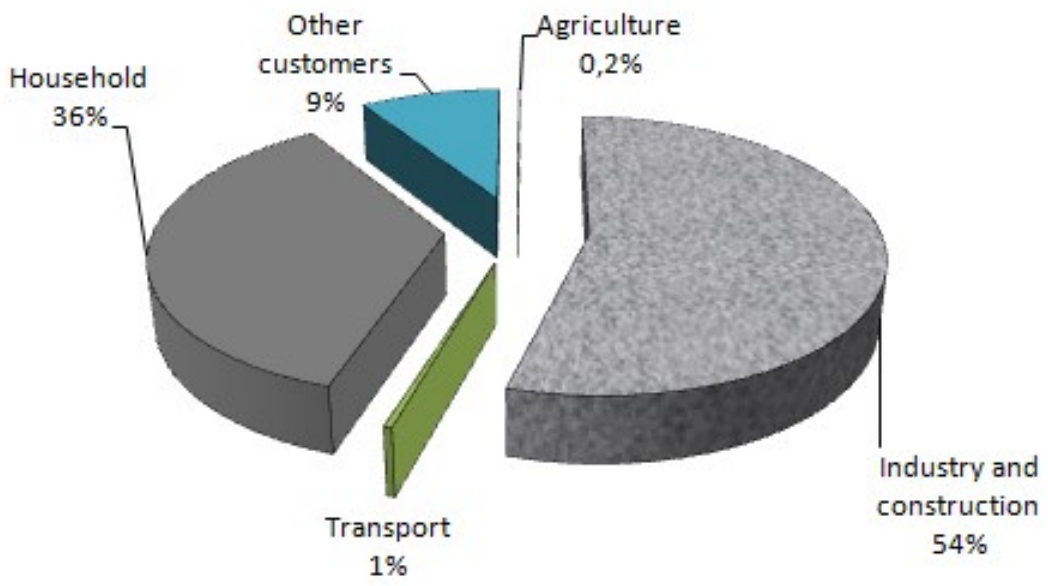

Fig. 6. Heat consumption according to the Central Statistical Office in 2016 [\%] [19-21].

Electricity consumption increases every year, which is critical to the environment. The analysis of Figure 6 shows that the industry and construction sector consumes more than half of the heat. The second place is occupied by households. It is necessary to promote the use of renewable energy sources in this area. The analysis of Figures 4-7 shows that the industry and construction sector has a large share in hard coal consumption (24\%), heat 
$(54 \%)$ and electricity (51\%). The analysis shows that the industry and construction sector consumes the most heat of all the business sectors.

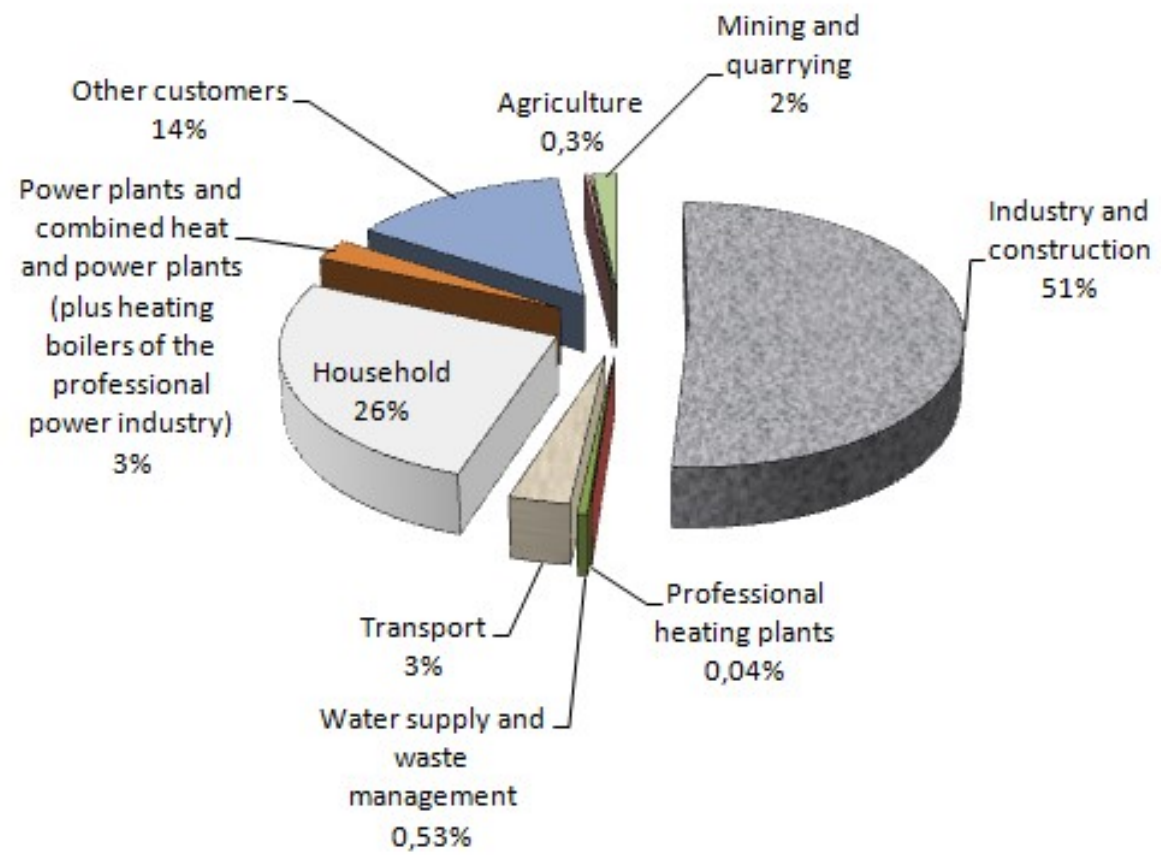

Fig.7. Electricity consumption in individual sectors of the economy [19-21].

The consumption in individual areas leads to the conclusion that huge benefits can be derived from rational management in the construction sector and the related sector of households. Fig. 8 presents the structure of percentage consumption of hard coal, heat and electricity for 2016, 2015 and, for comparison, 2010.

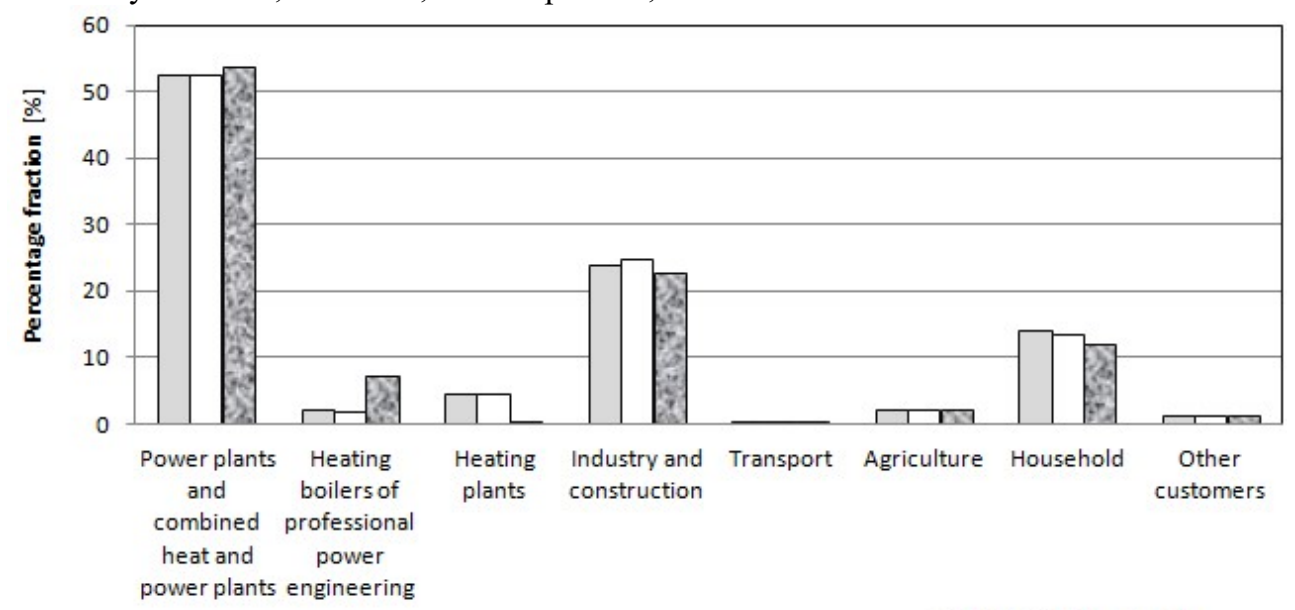

The economy sector

Fig. 8. The consumption of hard coal for individual sectors of the economy [19-21]. 
Analysis of the figure reveals that in 2016, the highest share in consumption of brown coal was observed compared to the level recorded 6 years before in the sector of the industry and construction. In the case of households, hard coal consumption is increasing.

\section{Conclusion}

The analyses reveal that the construction sector represents the sector of the economy which substantially impacts (directly and indirectly) on the condition of the natural environment. This sector consumes great amounts of coal and electricity. In the sector of households, hard coal consumption is constantly increasing, similar to electricity consumption.

The analysis shows that:

- The largest amount of carbon dioxide is emitted by energy industries (53\%).

- The largest amount of waste is generated by the mining and quarrying sector (47\%).

- The industry and construction sector consumes $24 \%$ of hard coal.

- The household sector consumes $14 \%$ of hard coal, $36 \%$ of heat and $26 \%$ of energy (2016).

- The industry and construction sector consumes more than half of heat (54\%).

Emissions of pollutants are very dangerous to the environment. The alternative methods to organize all the stages of the construction process should be proposed such that they do not have a negative impact on the environment. It is necessary to use renewable energy sources on a large scale.

\section{References}

1. Report of the United Nations Conference on Environment and Development. Rio de Janeiro, 3-14 June 1992 T.I. United Nations, New York, 528 (1993).

2. A. Czajkowska, M. Kadłubek, Management of Factors Affecting Quality of Processes in Construction Enterprises. Polish Journal of Management Studies. No1, s.28-38, ISSN 2081-7452 (2015).

3. A. Czajkowska, M. Ingaldi, Analysis of the impact of individual phases in the building process cycle on the environment with respect to the principles of sustainable development, $2^{\text {nd }}$ International Conference on the Sustainable Energy and Environment Development - SEED'17 (to be published)

4. J. Szajnar, A. Walasek, C. Baron, Tribological and corrosive properties of the parts of machines with surface alloy layer, Archives of Metallurgy and Materials, vol. 58, iss. 3, s. 931-936. (2013).

5. A. Czajkowska, Various aspects of the quality of the materials and processes used in the construction industry, scientific elaboration up and editing dr inż. Agnieszka Czajkowska, Kielce University of Technology Publishing, Kielce. (2015).

6. Gil-Mastalerczyk, Unconscious aspects of sustainability in modern and postmodern religious architecture in Poland. E3S Web of Conferences - International Conference on Sustainable Energy and Environment Development, SEED 2016, AGH University of Science and Technology Faculty of Energy and Fuels, (17-19.05) Kraków, Tom: 10, Strony: 1-8. (2016).

7. S. M. Wierzbicki, R. Gajownik, Problemy zrównoważonego budownictwa w pracach Instytutu Techniki Budowlanej [In:] Konferencja Naukowo-Techniczna „Budownictwo spełniające wymagania zrównoważonego rozwoju”, ITB, Mrągowo, pp. 34-42. (2002). 
8. N. Safronova, E. Nezhnikova, A. Kolhidov, Sustainable Housing Development in Conditions of Changing Living Environment. MATEC Web of Conferences 106, 08024 (2017).

9. Constitution of the Republic of Poland of April 2 (1997).

10. M. Zaharia, R. M. Gogonea, A. Tănăsescu, Characteristics of the evolution of renewable energy production in European Union, MATEC Web of Conferences 126, 04003 (2017).

11. K. Szczepaniak, System zarządzania energią w warunkach zrównoważonego rozwoju. Zarządzanie i Finanse Journal of Management and Finance Vol. 12, No. 4 (2014)

12. Ustawa z dnia 27 kwietnia 2001 r. - Prawo ochrony środowiska (t.j. DzU z 2008 r. nr 25, poz. 150 z późn. zm.).

13. Rozporządzenie parlamentu europejskiego i rady (UE) NR 305/2011 z dnia 9 marca 2011 r. ustanawiające zharmonizowane warunki wprowadzania do obrotu wyrobów budowlanych i uchylające dyrektywę Rady 89/106/EWG.

14. The Act of 8 September 2016. Construction Products (Journal of Laws of 2016, item 1570).

15. The Directive 2009/28/EC on the promotion of the use of energy from renewable sources. (sets targets for all member states, such that Poland will reach a $15 \%$ share of energy from renewable sources by 2020)

16. The Act of 20 February 2015 on renewable sources of energy (Journal of Laws of 2015, Pos. 478).

17. The Building Law Act of 7 July 1994 (Journal of Laws 2017, Pos. 1332) with further amendments.

18. Eurostat Database

19. Rocznik statystyczny Rzeczypospolitej Polskiej, 2016.

20. Consumption of fuels and energy carriers in 2015, CSO, Production Department, Agencja Rynku Energii S.A. Energy Market Agency, Warsaw (2016).

21. Consumption of fuels and energy carriers in 2016, CSO, Production Department, Agencja Rynku Energii S.A. Energy Market Agency, Warsaw (2017). 